\title{
A Brief Discussion on Legal Guarantee of Industry Security in Foreign Capital Merger and Acquisition
}

\author{
Bingyu Liu \\ School of Law, Minzu University of China \\ Beijing 100081, China \\ E-mail: gloria5885@126.com
}

\begin{abstract}
Foreign capital merging and acquiring China enterprises has recently become an economic and legal hotspot event that has attracted extensive attentions, and practice has proven that merging and acquiring leading enterprises and in turn controlling the overall industry to monopolize the industry have seriously endangered the industry security of China. Limited by various imperfections in legal force and application, the existing laws cannot fundamentally protect the industry security in foreign capital merger and acquisition. To improve the legal system for the supervision over foreign capital merger and acquisition, and establish the legal mechanism for industry security and industry policy are effective legal measures to solve the issue of industry security in foreign capital merger and acquisition.
\end{abstract}

Keywords: Foreign capital merger and acquisition, Industry security, Legal guarantee

One of the remarkable symbols of economic globalization is international investment. Direct investment in which investors run enterprises directly overseas and have a relatively big power to control the operation and management of enterprises is having a major influence in international economy. Reading the history of the economic open-up in 30 years, one finds that the mode with which multinationals invest in China develops from contracted operation of Chinese-foreign equity joint venture, Chinese-foreign cooperative joint venture, and solely foreign-owned business in the initial period to the current investment mode mainly characterized by merger and acquisition. In recent years, the issue that foreign investors' merger and acquisition of domestic enterprises influences industry security, national economic security and even national security, which is triggered by Coca Cola's merger and acquisition of Huiyuan and Carlyle's merger and acquisition of XCMG, has attracted extensive attentions, forcing China to re-think about foreign capital merger and acquisition.

\section{Definition of industry security and influence}

The industry security refers to the fact that in international economic competition, the industries of a country can develop healthily, soundly, and sequentially, and maintain leading positions or can be in advantageous statuses, particularly to the independence of domestic industries from foreign countries in aspects such as knowledge and technologies, and to the realization of support functions for the development of national economy (Xie Ying, 2005, p.36). This definition includes the following key points: Firstly, industry security mainly copes with key industries instead of all industries of a country. It copes with some key industries, such as strategic resources (energy and water resources) industries, major equipment manufacturing industry, financial industry and ones involving environmental and ecological security. Secondly, it is necessary to view the industry security from the height of national development strategy. Whether an industry is secure or not discussed only in terms of the industry itself, and it is necessary to go beyond the "industry security" and view the industry security from the strategic height of national interests and from the angle of long-term social interests.

The evaluation of the influence of foreign capital merger and acquisition on industry security should be established on the basis of the understanding of the value of foreign capital. Since reform and open-up, the role that foreign capital has played in China's introduction of advanced technologies, management, and talents, and the achievements we have made in these aspects are obvious to people, and it can be said without any exaggeration that it is foreign investment that has put China into the track of economic globalization. But the international lesson that depending too much on foreign capital objectively leads to the economic hollow-out of a country makes us re-position the use of foreign capital. Against the background of having joined the WTO, economic globalization and trade liberalization, the concept of overlooking the negative influence of foreign capital merger and acquisition on domestic industry security and economic security is more harmful because 
market economy and globalization can neither transcend national interests, nor automatically maintain national interests and industry security. In the practice of foreign capital use in China, the phenomenon that foreign capital has reached monopoly or control position in some industries in China is already extraordinarily serious. Multinationals have already formed a situation of monopoly on products in China such as mobile telephone, program-controlled switch, computer, electronic components, sedan, machine tool, and video recorder. Some newspapers and magazines have also used statistics data to show that foreign investors have reached the control position in industries such as rubber, tire, beer, paper making, cleansing articles, and medicine. Many examples have shown that merger and acquisition, foreign capital usually ceases the operation of domestic enterprises so as to wipe out competitors and to obtain domestic market-share or transforms merged and acquired enterprises into pure processing plants in order to keep them far away from intellectual property rights and core technologies. Intellectual property right law barrier makes it very difficult for China to change her low-end position in the international industry chain, and the weakening of industry competitiveness and the control of enterprises by foreign capital directly lead to the loss of the national carrier for independent innovation. Therefore almost all developed countries take national industry security and economic security as top factor for consideration in legislation and management of industry security examination for foreign capital merger and acquisition.

It is necessary to correctly understand and handle the issue of industry security generated by foreign capital merger and acquisition in China. What is the most important is to necessarily understand the importance of industry security from the strategic height of national interests, and the main influences generated by foreign investors' merging and acquiring enterprises, which involve industry security, include: Selling state-owned assets at an extremely low price, allowing foreign capital to merger and acquire leading enterprises of advantageous industries in China, which necessarily reduces the competitiveness of China enterprises, and allowing foreign capital to control the lifeline of key equipment manufacturing industry of China, which threatens the national economic security and national security.

\section{An analysis of laws and regulations in force of China}

The pouring-in of large quantities of foreign capital and its merging and acquiring domestic enterprises necessarily trigger the issue of industry security. Therefore, developed countries in America and Europe have all been making efforts to take antimonopoly as the top task in regulating foreign capital merger and acquisition, and establish it as the basic principle in regulating foreign capital merger and acquisition behaviors. The advanced law making experiences of foreign countries and the severe reality that foreign capital occupies domestic market in China have both shown that it is necessary to follow the law of market economy in the practice of formulating legal system for foreign capital merger and acquisition and of regulating foreign capital merger and acquisition, so as to reasonably regulate the further development of the phenomenon that foreign capital monopolizes domestic market.

There are problems with the influence of foreign capital merger and acquisition activity on industry security. The main reason is that the basic legal system that protects the industry security, such as the State Security Law of the People's Republic of China, has not yet been established; and the industry security has not been defined and certified in the legal sense. The stipulations of the laws in force of China on the contents of supervision over industry security in foreign capital merger and acquisition are very simple and in principle, and there is no complete, specific, and operational stipulation on entity standard for supervision over foreign capital merger and acquisition, so in practice, it is difficult for the state to realize effective regulation, according to law, on the activity of foreign capital merger and acquisition. For example, for monopoly in merger and acquisition, Regulations on Merger only stipulates in principle: "Enterprise merger shall both promote economy of scale and prevent the formation of monopoly to facilitate competitions among enterprises". China laws have so far no specific stipulations on the material issues of prohibiting monopoly, such as the definition of monopoly, formation, supervision and administration, and punishment. In foreign capital policy, China laws have not clarified the issues as to the industries of China in which foreign capital can make merger and acquisition, the qualification that foreign investors must have in foreign capital merger and acquisition, and how to determine the treatment for foreign investors in foreign capital merger and acquisition, and the laws in force of China have no definite stipulations.

Moreover, foreign capital merger and acquisition involves the issue of industry security, currently in china, there is still no law that is formulated by the National People's Congress of China and its Standing Committee, namely, the law for foreign capital merger and acquisition in the strict sense. China's direct or indirect regulation and policy system for the approval and the supervision of foreign capital in merging and acquiring domestic industries is confused, and the relevant regulations and policies are promulgated by different departments whose legal forces are not so high, so many merger and acquisition cases in practice are difficult to operate, and there 
are a lot of contradictions too, which make it difficult to standardize and restrict the influence of foreign capital merger and acquisition on industry security. The clauses of regulations involving foreign capital merger and acquisition, which are about foreign capital merger and acquisition, basically have nothing more than the contents such as industrial and commercial approval, general terms and conditions for entry, foreign enterprise form and operation, and foreign capital protection policy, and there is no pertinent policy based on industry security and economic security. For example, Provisions for Foreign Investors to Merge and Acquire Domestic Enterprises revised by the Ministry of Commerce of the People's Republic of China and other departments, has devised stipulations on the merger mode, basic system, approval, registration and antimonopoly examination for foreign capital to merge and acquire domestic enterprises. Article 12 of the provisions stipulates that foreign capital merger and acquisition that involves key industries or may possibly influence national economic security and industry security shall be reported to competent authorities for approval. But the issues as to whichever industries are included in key industry, how to define economic security, and the specific regulations and policies to restrict foreign capital merger and acquisition are not clarified, so effective operation in practice is very difficult. Form this, it can be seen that China has failed to attach sufficient importance to the economic or political insecurity possibly generated by the merger and acquisition of a certain industry or the monopoly of the merger and acquisition of the same industry.

\section{Improve regulations on solving legal guarantee mechanism for industry security in foreign capital merger and acquisition}

Foreign capital merger and acquisition has already formed a considerably big threat to the industry security of China, so it is very necessary to establish security and guarantee mechanism on foreign capital merger and acquisition and improve the corresponding legal system. Therefore, China must strengthen the study of entity standard for supervision over foreign capital merger and acquisition, and reflect it in relevant laws as soon as possible to meet the need of the state to implement supervision over foreign capital merger and acquisition. Based on the civil and commercial behaviors that foreign capital merger and acquisition activities have, the supervision over foreign capital merger and acquisition should not be limitless intervention and control over foreign capital merger and acquisition, or arbitrary interference in enterprises' autonomy in management or limitation on fair competition in investment field. It is necessary to exercise supervision right, from the overall interests of the state and the society, in the relevant fields in foreign capital merger and acquisition activities, where it is necessary for state public power to intervene, and to regulate non-standard and illegal merger and acquisition behaviors. In a word, the supervision of the state over foreign capital merger and acquisition should focus on the market access of foreign capital merger and acquisition, on foreign investors in foreign capital merger and acquisition, the investment ratio of foreign investors in foreign capital merger and acquisition, on the protection of state-owned assets in foreign capital merger and acquisition and on the regulation of monopoly in foreign capital merger and acquisition.

\subsection{Supervision over investment ratio of foreign investors in foreign capital merger and acquisition}

Market access is the first system barrier set up by the host country for foreign capital merger and acquisition. To make laws to make it clear that supervisory departments have the right to conduct special control, according to law, over some industries which are very important economically or very sensitive politically in order to prohibit or restrict the occurrence of merger and acquisition behavior in these industries is common international practice. For example, the Fair Trading Act of Britain stipulates, to merger and acquisition industries such as oil, banking, insurance and financial services, telecommunications, natural gas, tap water supply, and press, the merging and acquiring party needs to obtain in advance the special permit of the relevant competent government authorities of Britain. By comparison, China fails to attach sufficient importance to the economic or political insecurity possibly generated by the merger and acquisition of a certain industry, and the monopoly possibly generated by the merger and acquisition of the same industry. On the issue of market access for foreign capital merger and acquisition, departments of supervision over foreign capital merger and acquisition should have special control right. (Huang Ning, 2002, p.56-58) Supervisory organizations shall review and examine, in accordance with statutory standards, matters such as the investment field of foreign capital merger and acquisition, and its potential influence on the relevant markets and target enterprises of China. For all cases that comply with legal stipulations, supervisory organizations shall approve the implementation of the merger and acquisition behaviors of foreign investors, otherwise, supervisor organizations shall not approve the implementation of the merger and acquisition behaviors of foreign investors, and through investigation or examination by supervisory organizations, supervisory organizations shall decide whether to terminate the merger and acquisition or not. For any enterprise merger and acquisition that has been completed without examination and approval, supervisory organizations shall have the right to sentence the merger and acquisition thereof to be null and invalid. 
Supervisory organizations can impose administrative punishment on parties who implement merger and acquisition in violation of procedure.

\subsection{Supervision over subjects of foreign capital merger and acquisition}

The subjects of foreign capital merger and acquisition are foreign investors in the merger and acquisition, and the supervision and management over them is mainly to define whether foreign investors have the corresponding legal status and the behavioral competence for merger and acquisition. In special cases, in consideration of maintaining national economic security, China needs to restrict the merger and acquisition qualification of the following several kinds of foreign investors who participate in merger and acquisition. Firstly, only foreign juridical persons or other commercial organizations can participate in merger and acquisition in China. To avoid monopoly, political monopoly in particular, foreign state companies and governmental organizations shall not participate in merger and acquisition in China. Secondly, whether a foreign investor can participate in merger and acquisition in China or not is related to whether the investor has "affiliated enterprises" (Note 1) in China and the relation between the "affiliated enterprises" and the merger and acquisition deal the foreign investor plans to make this time. State organizations of supervision over foreign capital merger and acquisition shall prohibit foreign investors from participating, through their foreign-funded enterprises established in China, in merging and acquiring enterprises in industries which foreign capital is not allowed to enter or restricted to enter; and it is also necessary to prohibit investors, who have established sub-companies or subsidiaries to provide a certain product or service in China, from merging and acquiring another enterprise of China that provides the same product or service in order to prevent monopoly.

\subsection{Establish legal system for examination of national industry security in foreign capital merger and acquisition}

Control the investment ratio of foreign investors in foreign capital merger and acquisition. The investment ratio of foreign investors in merging and acquiring industries which foreign investors are restricted to enter is the key point to prevent this industry from being controlled by foreign capital. For this, China should establish the pre-event application system and the after-event report system for foreign capital merger and acquisition to prevent foreign capital from controlling enterprises of some industries of China through merger and acquisition. Upon the completion of merger and acquisition and within certain years after the completion of merger and acquisition, a merged and acquired enterprise shall continually report to supervisory organizations the share holding status of the enterprise after the merger and acquisition, and once the investment ratio of a foreign investor is found to exceed the control right ratio specified by the State, which forms control over the enterprise of China, the supervisory organizations shall have the right to deem the investor has violated the law and to order that the merged and acquired enterprise be dissolved, or the foreign investor to return the share or asset he/she has purchased.

In regulating the industry security generated by capital merger and acquisition, the U.S. adopts classified administration. For general competition industry security, Antitrust Law is used to prevent foreign capital from conducting malignant acquisition; Merger and Acquisition Act for Listed Companies and Securities Investment Control Regulations are used to limit companies listed in the stock exchange; for industries or core technology industries relating to national economy and people's livelihood, define and examine the industry security according to National Security Act. To deal with the issue of domestic industry security triggered by foreign capital merger and acquisition, Law on Examination of National Industry Security in Foreign Capital Merger and Acquisition of the People's Republic of China formulated by the Standing Committee of the National People's Congress of China, sets up a transnational merger and acquisition examination organization and establishes the regulation scope of foreign capital merger and acquisition. While endowing foreign capital with national treatment, it also confirms the industries and fields in which foreign capital merger and acquisition are limited, regulates the examination and approval system for foreign capital merger and acquisition, and focuses key points of examination on strategic industries, and key fields include key fields in agriculture, industry, and financial industry.

\section{Ending remarks}

Of course, it is also necessary to have some restrictions for the antimonopoly of foreign capital merger and acquisition. As one of the modes for enterprise mergers and acquisition, foreign capital merger and acquisition is a kind of transnational investment legal behavior in which foreign investors having equal legal positions and domestic enterprises participate voluntarily, it must follow the principle of autonomy of will, and direct government intervention should be avoided. Due to the fact that in China, the status that there is no separation between governments and enterprises, no separation between governments and capital, has not been changed fundamentally, foreign capital merger and acquisition is, to a certain extent, the result of the push of the 
governmental will, and it is unavoidable to replace economic target with non-economic target. It is necessary to realize the reasonable positioning of government's role in the practice of foreign capital merger and acquisition to ensure that foreign capital merger and acquisition activities are carried out by foreign investors and domestic enterprises under the principle of "voluntariness and effect".

Against the background of market economy and economic globalization, to maintain the industry security of a country, it is necessary to learn and absorb, with an open view, advanced legal guarantee mechanisms of foreign countries, and establish a series of measures, including reasonable competition policy, perfect early warning mechanism, and feasible trade aid mechanism; but fundamentally speaking, it is necessary to improve independent innovation capability and to improve the competitiveness of China's industries. It is necessary to make laws to enlarge and encourage investment in the research and development of technologies, to guide the orientation of capital investment in independent innovation industries, and to focus on supporting transnational groups and advantageous industries with international competitiveness in order to establish international comparative advantage.

\section{References}

Huang Ning. (2002). A Study on Legal System for Foreign Capital Merger and Acquisition in China. Administration and Law, (7): 56-58

Ji, Baocheng. View on Some Issues of Industry Security in China. [Online] Available: www.sina.com.

Xie, Ying. (2005). Theory and Practice of National Industry Security. China Commerce and Trade Press, 36.

Wang, Dongyun. (2000). Status Quo and Trend of Multinationals' Direction Investments in China. World Economy Study, (3): 45.

Zhang, Yong. A Study on Legal System for Examination of Nation Industry Security in Foreign Capital Merger and Acquisition in the U.S. and Canada.

\section{Note}

Note 1. For definition of "associated enterprises", see the legal documents, such as notice on printing and delivering Accounting Standard for Business Enterprises-Associated Party Relation and Disclose of Their Transactions released on May 22, 1997 by the Ministry of Finance of the P.R.C. 